\title{
Draining an unproductive black spruce peatland stand: 18-year post-treatment tree growth and stand productivity estimation
}

\author{
by Sylvain Jutras ${ }^{1}$, Jean Bégin ${ }^{2}$, André P. Plamondon ${ }^{3}$ and Hannu Hökkä4
}

\begin{abstract}
In the eastern Canadian boreal forest, drainage of unproductive black spruce peatlands is an infrequently used silvicultural treatment. The sparse scientific literature concerning its influence on tree growth is, however, relatively positive about the possibility of using drainage to convert unproductive stands into productive ones. This study aimed to address this issue by assessing the individual tree growth and by estimating the future stand productivity on a drained black spruce peatland stand. Results showed larger mean annual post-drainage stump diameter increment with increasing ditch proximity but they also showed the lack of effect of the treatment at distances greater than $15 \mathrm{~m}$ from the ditch. Small-sized trees reacted more strongly to the treatment than larger ones. Estimated site productivity was also influenced by the ditch proximity. The presence of excavating mounds on only one side of the ditch greatly influenced tree growth and site productivity. Considering the obtained results, intensive drainage operations, utilizing narrow ditch spacing, would be necessary in order to transform the type of unproductive sites studied into productive ones.
\end{abstract}

Key words: diameter growth, site index, forested peatland, forest drainage, Picea mariana

\section{RÉSUMÉ}

Le drainage de peuplements forestiers improductifs tels que les pessières noires sur sol organique est un traitement sylvicole marginal en forêt boréale de l'est du Canada. La littérature scientifique à ce sujet est rare et relativement enthousiaste à propos de la possibilité d'en obtenir éventuellement des peuplements productifs. Cette étude visait à clarifier cette possibilité en mesurant la croissance de tiges individuelles d'épinette noire et en estimant la productivité future d'un peuplement improductif drainé. Les résultats ont démontré des accroissements annuels moyens postdrainage en diamètre à la souche augmentant avec la proximité du fossé. Toutefois, ce traitement a peu d'effet à des distances supérieures à $15 \mathrm{~m}$. Les arbres de petite dimension ont plus fortement réagi au traitement que les arbres plus gros. La productivité a aussi été influencée par la proximité des fossés. La présence de butons d'excavation sur un seul coté des fossés s'est avérée déterminante pour la croissance forestière et la productivité du site. En considérant les résultats obtenus, l'emploi de réseaux de drainage intensifs utilisant des espacements étroits entre les fossés semblerait nécessaire afin de rendre productif le type de peuplement improductif ayant été étudié.

Mots-clés : croissance en diamètre, indice de qualité de station, tourbière forestière, drainage forestier, Picea mariana

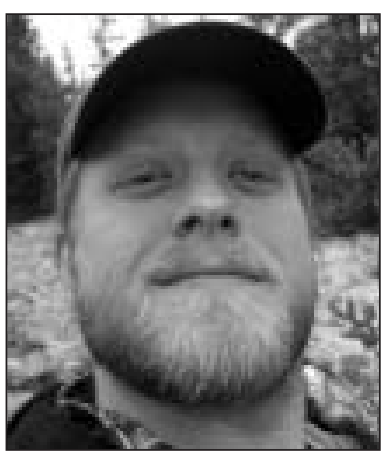

Sylvain Jutras

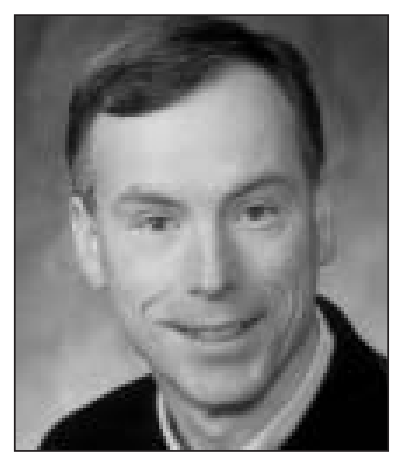

Jean Bégin

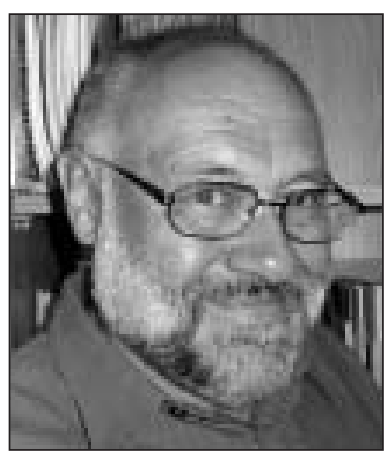

André P. Plamondon

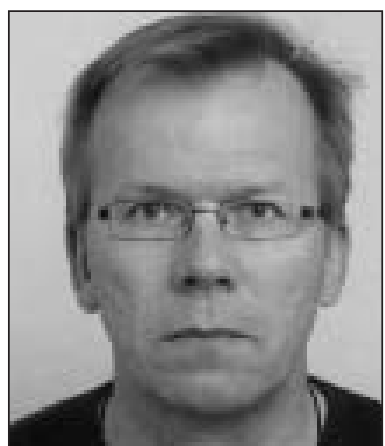

Hannu Hökkä

\footnotetext{
${ }^{1}$ Forest Biology Research Centre, Université Laval, Ste-Foy, Québec G1K 7P4. E-mail: sylvain.jutras.1@ulaval.ca

${ }^{2}$ Faculty of Forestry and Geomatics, Université Laval, Ste-Foy, Québec G1K 7P4. E-mail: jean.begin@sbf.ulaval.ca

${ }^{3}$ Forest Biology Research Centre, Université Laval, Ste-Foy, Québec, G1K 7P4. E-mail: andre.plamondon@sbf.ulaval.ca

${ }^{4}$ Finnish Forest Research Institute, Rovaniemi Research Unit, P.O. Box 16, FIN 96301 Rovaniemi, Finland. E-mail: hannu.hokka@metla.fi
} 


\section{Introduction}

The periodically revived threat of wood supply shortage has brought Canadian foresters to think about different ways to avoid this undesirable outcome. Managing slow-growing and stagnant boreal black spruce (Picea mariana (Mill.) BSP) peatland stands by draining them to achieve greater stand merchantability has been suggested by numerous authors in Alberta (Wang et al. 1985; Hillman 1987, 1991a, b; Dang and Lieffers 1989; Hillman and Takyi 1998), in Ontario (Stanek 1968, 1977; Payandeh 1973a, b, 1975, 1982, 1989; Rosen 1989; Jeglum 1991a, b), in Québec (Stanek 1970, Nadeau and Parent 1982, Zarnovican 1989) and in Newfoundland (Heikurainen 1968, Pollett 1969, Päivänen and Wells 1978).

In Quebec, unproductive boreal peatland stands, by definition, support less than $30 \mathrm{~m}^{3}$ /ha of merchantable timber at 120 years (Saucier 1994). These stands have a site index of $3 \mathrm{~m}$ or less at 50 years (Payandeh 1978, 1990). They correspond to various ecological types, from treeless to sparsely wooded peatlands such as treed ombrotrophic bogs and extreme poor treed fens (e.g., Jeglum 1991c). According to the $3^{\text {rd }}$ Provincial Forest Inventory, unproductive peatland stands cover about 4 Mha, which represents $6.7 \%$ of Quebec's total land cover under forest management. On these boreal sites, black spruce is the most abundant commercial tree species. Tamarack (Larix laricina (Du Roi) K. Koch), balsam fir (Abies balsamea (L.) Mill.) and eastern white-cedar (Thuja occidentalis L.) are occasionally found in small numbers. The high water table level and poor nutrient availability that characterise such sites severely limit tree growth (Payandeh 1973a, Leiffers and Rothwell 1986, Leiffers and Macdonald 1990).

Forest drainage is a silvicultural treatment that removes excess soil water through a network of inter-connected ditches, thereby lowering the water table of peatland sites (Heikurainen 1964, Paavilainen and Päivänen 1995, Lieffers and Rothwell 1987, Hillman 1992, Roy et al. 2000). Following this treatment, soil aeration can be improved, peat decomposition accelerated and nutrient availability increased (Lieffers and Rothwell 1987; Lieffers 1988; Prévost et al. 1997, 1999; Roy et al. 2000). Slow-growing black spruce subsequently can show enhanced annual diameter and height increments (Payandeh 1973a; Jutras et al. 2002; Prévost et al. 2005). The most favourable reactions to this treatment have been reported for small trees (Macdonald and Yin 1999) and for trees located in close proximity to ditches (McLaren and Jeglum 1998), while old and narrow-crowned trees are not likely to show response to drainage (Stanek 1968). Black spruce often has shown delayed growth reactions to improved soil conditions, with significant growth increments appearing only in the sixth year after drainage (McLaren and Jeglum 1998; Dang and Lieffers 1989). Consequently, most studies evaluating five-year post-treatment black spruce growth have revealed no significant reaction to drainage (Payandeh 1982, Sundström 1992, Sundström and Jeglum 1992, Prévost et al. 1999).

In Canada, many papers have been published concerning the positive effects of forest drainage on tree growth in midrotation or pre-mature stagnant peatland stands. Some of the more enthusiastic articles leave readers perplexed concerning the validity of their silvicultural recommendations (Stanek 1968, Nadeau and Parent 1982, Wang et al. 1985, Bolghari 1986, Zarnovican and Laberge 1994). Data selection often was questionable and the statistical analysis inappropriate, if not absent. Few well-designed, reproducible experiments have studied drainage of pristine black spruce peatland stands in the Canadian boreal forest (Payandeh 1973a, Stanek 1977, Dang and Lieffers 1989, McLaren and Jeglum 1998, Macdonald and Yin 1999, Prévost et al. 2005). When drainage is applied at mid-rotation on a relatively fertile, densely stocked, productive peatland stand, reasonable increases in stand yield can be expected (Payandeh 1973a, McLaren and Jeglum 1998, Macdonald and Yin 1999). However, no concrete management recommendations have originated from these studies. Also, very little is known about the potential transformation of unproductive peatland sites into productive ones, since only Stanek (1977) estimated the growth reaction of black spruce after drainage in such stands.

Even if its effect on growth and productivity is still undetermined, drainage is practised, although not frequently, in Quebec unproductive black spruce peatlands. With the growing interest in intensive management (Coulombe et al. 2004), drainage may regain popularity in eastern Canada boreal regions where forested peatland stands cover wide areas. In the Canadian boreal forest, the oldest scientifically designed drainage experiments were established in the early 1980s (Hillman 1987, Bolghari and Veilleux 1987, Paavilainen and Päivänen 1995). In order to compensate for the lack of long-term information, Stanek (1977) used Plonski's (1974) yield tables while attempting to estimate the future yield of drained sites by monitoring alterations to the site index following drainage. Payandeh (1978) later demonstrated that the data used to create these yield tables grossly overestimated the true site index for short and old peatland black spruce stands, and suggested new height growth and site index formulae.

Using one of the oldest experimentally drained unproductive peatland stands of eastern Canada, we assessed the 1984-2002 post-drainage stump diameter increment of black spruce trees in relation to ditch proximity and initial size. In this strongly uneven-sized, slow-growing stand, we hypothesised that black spruce diameter increment would be significantly greater for trees located in the first few meters from the ditch, and mainly for small-sized trees. Secondly, the change in site index that followed drainage operations was monitored as a function of ditch proximity and tree size. Using these site productivity estimation values and Payandeh's (1990) yield tables, we later tested the hypothesis that, even with optimistic assumptions, the minimal value of stand productivity would not be reached on an unproductive black spruce peatland stand drained 18 years earlier.

\section{Materials and Methods}

The study area $\left(49^{\circ} 28.7^{\prime} \mathrm{N}, 74^{\circ} 38.3^{\prime} \mathrm{W}\right)$ is located $60 \mathrm{~km}$ south of the town of Chapais, Quebec, Canada. In 1984, a 15-ha unproductive uneven-sized black spruce stand was drained for experimental purposes. This study site was part of a larger research project of the Ministry of Energy and Resources (Bolghari and Veilleux 1987), and was not followed after 1993. With the death of Bolghari, most information concerning the drained unproductive site and the network of permanent plots covering it was lost. However, the ditch network was still intact and the ecological descriptions of the sites were still available. Therefore, new experimental plots specifically designed to test the hypotheses were established in 2002. 
The site was described as a Chamaedaphne-dominated peatland stand or OG14, using the Ontario Forest Ecosystem Classification for the Clay Belt, site Region 3e (Jones et al. 1983). Using the Quebec Forest Ecosystem Classification (Bergeron et al. 1998), the site was described as a Picea mariana-Sphagnum ombrotrophic peatland stand or RE39/LEG CAL SPS. The upper canopy is composed exclusively of black spruce. The shrub layer is characterized by the presence of abundant Chamaedaphne calyculata (L.) D. Don. and Rhododendron groenlandicum (Oeder) Kron \& Judd, as well as Kalmia polifolia Wang., Kalmia angustifolia L. and Andromeda glaucophylla Link. The moss layer is dominated largely by Sphagnum flexuosum Dozy \& Molk., $S$. fuscum (Schimp.) Klinggr. and S. magellanicum Brid.; Pleurozium schreberi (Brid.) Mitt. is present in smaller proportions. The soil consists of a deep organic layer $(>0.9$ $\mathrm{m})$ composed of weakly decomposed sphagnum moss. The thirty-year mean annual precipitation, temperature and degree-days above $5^{\circ} \mathrm{C}$, obtained from the "Chapais 2" meteorological station $\left(49^{\circ} 46^{\prime} \mathrm{N}, 74^{\circ} 51^{\prime} \mathrm{W}\right)$, are $961.3 \mathrm{~mm}$, $0.0^{\circ} \mathrm{C}$ and 1235 degree-days, respectively (Environment Canada 2004).

Drainage has been executed using an excavator equipped with a "V"-shaped bucket. Overall, 12 secondary ditches, 0.9 $\mathrm{m}$ deep by $2 \mathrm{~m}$ wide and totalling $4 \mathrm{~km}$ in length, determined three different ditch spacings (20,40 and $60 \mathrm{~m}$ ) (Fig. 1). All excavated material was deposited in mounds of varying dimensions (1-3 $\mathrm{m}$ radius, $0.5-1.5 \mathrm{~m}$ high), and located at random along the south-western side of ditches. Three rectangular-shaped plots, $6 \mathrm{~m}$ wide and ditch-to-ditch length, were established in 2002 for each ditch spacing (Fig. 1). All plots were positioned randomly. All trees greater than $1.3 \mathrm{~m}$ in height in 2002 were located geographically in each plot using graduated tapes. For each tree, the distance to the center of the closest ditch (DIST) was measured at the nearest $5 \mathrm{~cm}$. Since the effect of DIST might depend on whether that ditch was located up-slope or down-slope, a categorical variable (DITCH: UP-SLOPE or DOWN-SLOPE) was used to identify

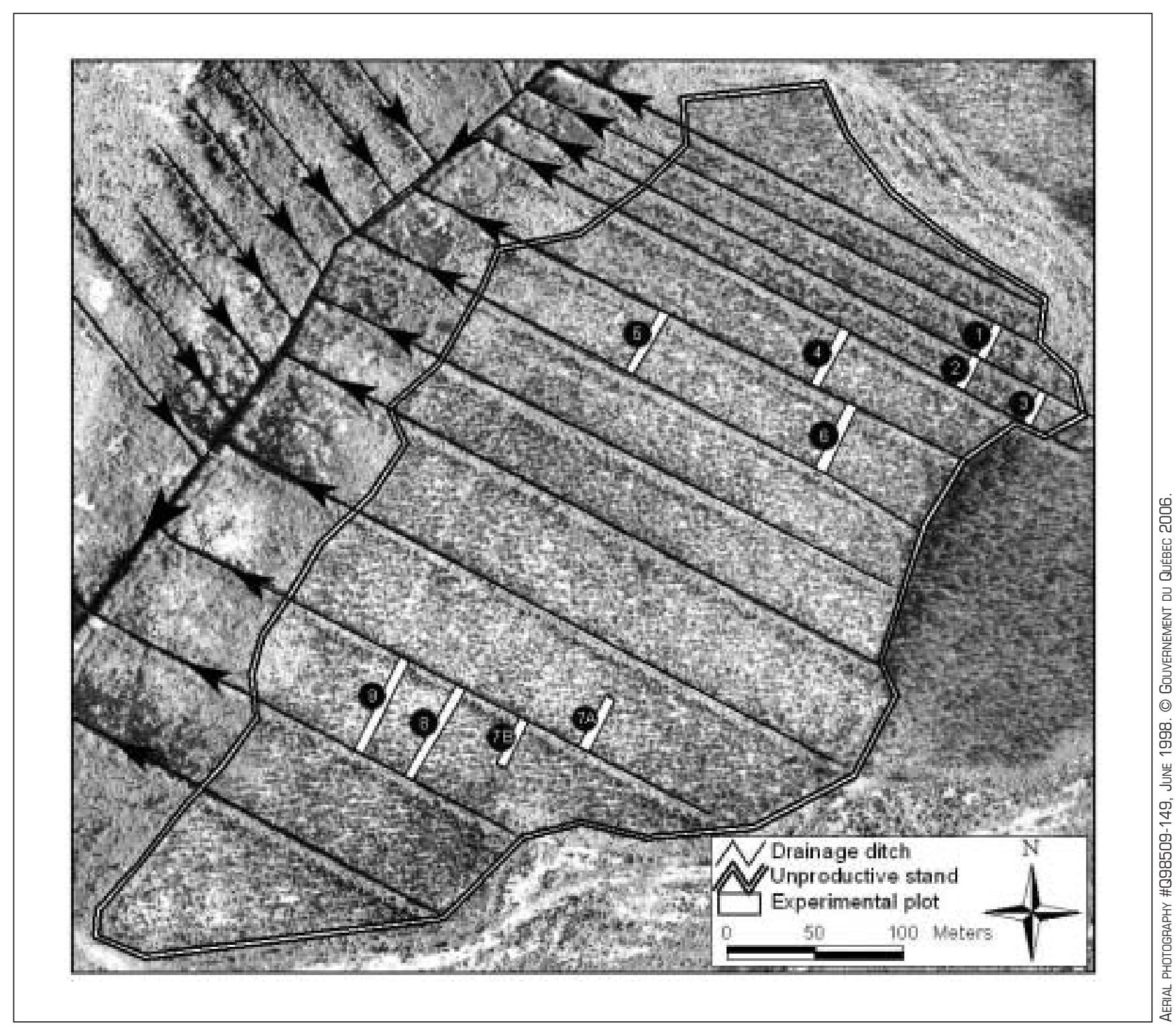

Fig. 1. Map of the drained unproductive black spruce peatland stand, showing the numbered experimental plot locations. Arrows indicate the direction of water flow. 


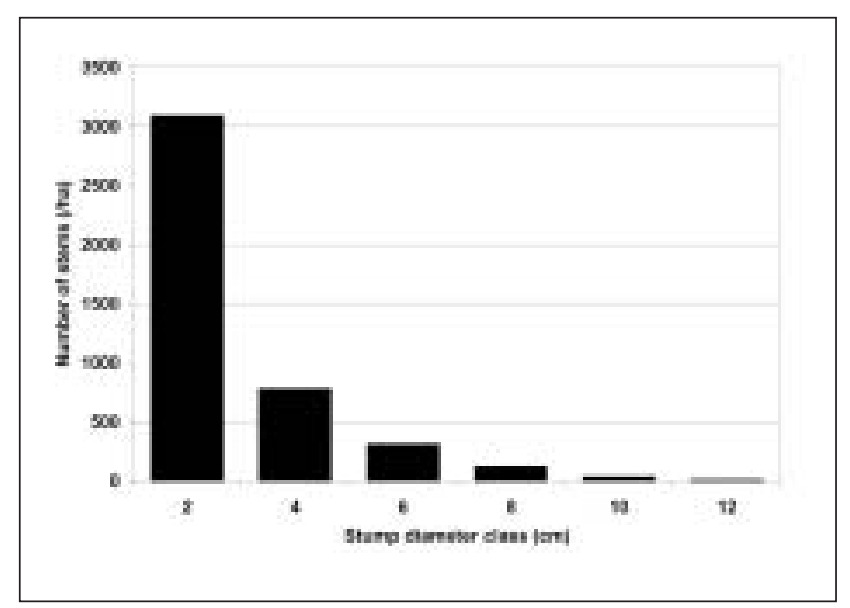

Fig. 2. Black spruce diameter distribution at the moment of drainage on an unproductive peatland stand.

the ditch nearest to the tree. All trees were felled and a wood disk was collected at stump height $(\mathrm{H}=0.3 \mathrm{~m})$. The five-year pre-drainage diameter increment (1979-1984) and the 18year post-drainage diameter increment (1984-2002) were determined from annual rings, which were measured on two perpendicular radii of the air-dried and sanded wood discs. Dendrochronological measurements were executed with a scanner and the WinDendro ${ }^{\mathrm{TM}}$ system (Regent Technology Inc., Sainte-Foy, QC, Canada) or a micro-metric table. The diameter distribution, reconstructed on the basis of the 967 black spruces to represent the situation at the time of drainage in 1984 confirmed the uneven-size structure of the stand (Fig. 2).

For each felled tree, total height was measured to the nearest $\mathrm{cm}$. The height at the time of drainage was estimated by counting down annual whorls on the stem. Since the exhaustive assessment of annual whorl scars was sometime imprecise, especially for slow-growing trees, a second disc was collected under the estimated 1984 whorl for all trees. After being air-dried and sanded, these discs were used to confirm or adjust the 1984 height estimates. Therefore, mean stem characteristics of the treated plots are summarised in Table 1.
Diameter growth assessment

Individual tree mean annual stump diameter increment for the 18-year post-drainage period (ADI84-02) was expressed as a function of the diameter at the time of drainage (D84) by means of analysis of covariance (ANCOVA). Logarithmic transformation of ADI84-02 and D84 was used to satisfy assumptions of normality and homogeneity of variance and to obtain a linear relationship between the two variables. The distance to the closest ditch (DIST), expected to show a nonlinear relationship with the response variable, was tested in the model with various transformations such as DIST, DIST ${ }^{2}$, DIST $^{0.5}$, DIST $^{-1}$ and $\ln$ (DIST). The reference ditch (DITCH: UP-SLOPE or DOWN-SLOPE) was used independently and in interaction with diameter and distance variables in the model. Growth variation among ditch spacings and plots were considered as random effects in the model. The MIXED procedure of SAS 9.1 (SAS Institute Inc. 2003) was used to perform the statistical analysis. All fixed and random parameters of the model were estimated simultaneously using the restricted maximum likelihood method. A level of significance of $5 \%$ was used throughout this analysis. Selection of each explanatory variable or interaction was based on its significant influence on the response variable and its influence on the $-2 \cdot \log$-likelihood value of the entire model. Minimising AIC (Akaike's Information Criterion) was an additional step used in selecting the final model.

\section{Stand productivity estimation}

By enhancing soil growing conditions, forest drainage is expected to positively affect site productivity of forested peatlands. Site index (SI), i.e., tree height at a given age, is a commonly used site productivity estimator and it is calculated from the height and age of a sub-sample of dominant or codominant stems selected within a plot. Payandeh's (1978) site index equation (Eq. 1) was used in this study since it is, to our knowledge, the only curve specifically adapted for low productivity black spruce peatland stands.

$$
\begin{aligned}
& S I=0.01835 \cdot H^{-0.18861} \\
& \quad\left(1-e^{-0.00009 \cdot A}\right)^{-0.81174 \cdot H^{0.1831}}
\end{aligned}
$$

Table 1. Black spruce diameters at stump height (DSH), stem heights $(H)$ and ages at stand drainage $(1984)$ and 18 years after drainage (2002), together with mean pre- and post-drainage annual diameter increments

\begin{tabular}{|c|c|c|c|c|c|c|c|c|c|}
\hline \multirow[b]{3}{*}{ Plot } & \multirow{3}{*}{$\begin{array}{l}\text { Spacing } \\
(\mathrm{m})\end{array}$} & \multicolumn{3}{|c|}{1984} & \multicolumn{3}{|c|}{2002} & \multirow{2}{*}{\multicolumn{2}{|c|}{$\begin{array}{c}\text { Mean annual stump } \\
\text { diameter increment }(\mathrm{mm} / \mathrm{y})\end{array}$}} \\
\hline & & DSH & $\mathrm{H}$ & & DCH & & & & \\
\hline & & $(\mathrm{cm})$ & $(\mathrm{m})$ & $\begin{array}{l}\text { Age } \\
(y)\end{array}$ & $(\mathrm{cm})$ & $(\mathrm{m})$ & $\begin{array}{l}\text { Age } \\
(y)\end{array}$ & 1979-1984 & 1984-2002 \\
\hline 1 & 20 & 1.5 & 1.58 & 45 & 3.9 & 3.31 & 54 & 0.38 & 1.37 \\
\hline 2 & 20 & 1.4 & 1.34 & 42 & 3.3 & 2.70 & 54 & 0.39 & 1.11 \\
\hline 3 & 20 & 1.7 & 2.57 & 37 & 4.6 & 3.74 & 49 & 0.55 & 1.64 \\
\hline 4 & 40 & 2.9 & 2.32 & 58 & 4.6 & 3.68 & 74 & 0.41 & 0.93 \\
\hline 5 & 40 & 2.7 & 2.27 & 58 & 4.4 & 3.48 & 73 & 0.41 & 0.93 \\
\hline 6 & 40 & 2.7 & 2.32 & 48 & 4.1 & 3.35 & 63 & 0.44 & 0.77 \\
\hline 7 & 60 & 2.8 & 2.29 & 48 & 3.9 & 3.25 & 65 & 0.45 & 0.63 \\
\hline 8 & 60 & 2.6 & 2.00 & 45 & 3.8 & 3.07 & 62 & 0.49 & 0.70 \\
\hline 9 & 60 & 2.7 & 2.15 & 50 & 3.8 & 3.01 & 66 & 0.40 & 0.62 \\
\hline All & & 2.5 & 2.13 & 49 & 4.0 & 3.23 & 63 & 0.43 & 0.85 \\
\hline
\end{tabular}


Table 2. Analysis of covariance (ANCOVA) of the 18-year postdrainage mean annual stump diameter increment (In(ADI84-02)]

\begin{tabular}{|c|c|c|c|}
\hline Source of variation & df & $F$-value & $p$-value \\
\hline \multicolumn{4}{|l|}{ Fixed variables } \\
\hline $\ln (\mathrm{D} 84)$ & 1 & 45.94 & $<0.0001$ \\
\hline DITCH & 1 & 24.09 & $<0.0001$ \\
\hline $\ln (\mathrm{D} 84) \times \mathrm{DITCH}$ & 1 & 16.40 & $<0.0001$ \\
\hline DIST & 1 & 41.66 & $<0.0001$ \\
\hline DIST $^{0.5}$ & 1 & 54.31 & $<0.0001$ \\
\hline DIST $^{-1}$ & 1 & 19.93 & $<0.0001$ \\
\hline DIST × DITCH & 1 & 12.59 & 0.0004 \\
\hline DIST $^{0.5} \times$ DITCH & 1 & 16.92 & $<0.0001$ \\
\hline DIST $^{-1} \times \mathrm{DITCH}$ & 1 & 19.70 & $<0.0001$ \\
\hline \multicolumn{4}{|l|}{ Random effects } \\
\hline Spacing & 2 & - & 0.2332 \\
\hline Plots & 8 & - & 0.0882 \\
\hline Residual error & 914 & - & - \\
\hline Corrected total & 931 & - & - \\
\hline
\end{tabular}

Note: D84 = diameter at the moment of drainage $(\mathrm{cm}) ; \mathrm{DITCH}=$ reference ditch $(0=$ UP-SLOPE, $1=$ DOWN-SLOPE $)$; DIST $=$ Distance to the center of the closest ditch $(\mathrm{m})$.

where $S I$ is the site index, i.e., the total tree height at 50 year; $H$ is the measured height at a given age; $A$ is tree age measured at stump height $(30 \mathrm{~cm})$.

Using a SI equation to assess the change in site productivity of a stand over a specific period of time requires the agreement of certain postulates. First, selected dominant and co-dominant stems should remain the same between two SI estimations to facilitate comparisons (Payandeh 1978, Hökkä and Ojansuu 2004). However, drainage is known to reduce size inequity of uneven-sized black spruce peatland stands (Macdonald and Yin 1999) since the growth reaction of small trees is more important than for larger ones. Considering only the tallest (and oldest) stems would result in the under-estimation of the overall stand productivity change since observations would be based on trees showing the smallest reaction to drainage. Therefore, the SI estimation method had to be adapted to our specific situation, where the growth reaction is expected to vary with respect to tree size and where the changing hierarchical height structure within the stands has to be considered. This has been achieved by initially dividing the previously described plots into subplots of fixed width (e.g., $10 \mathrm{~m}$ ) relative to the distance to the ditch $\left(\mathrm{CL}_{\text {DIST }}: 0-10 \mathrm{~m}, 10-20 \mathrm{~m}\right.$ and $\left.20-30 \mathrm{~m}\right)$ and by considering its effect combined with the reference ditch (DITCH: UPSLOPE or DOWN-SLOPE) on stand productivity. Stem size classes were determined within each subplot by ranking all the stems $(1, \ldots, n)$ in function of their height in 1984 and creating three classes of equal extent: SIZE; Small ( $\mathrm{rank}=1$ to rank $\left.=\frac{n}{3}\right)$, Intermediate $\left(\mathrm{rank}=\frac{n}{3}\right.$ to rank $\left.=\frac{2 n}{3}\right)$ and Large $\left(\right.$ rank $=\frac{2 n}{3}$ to rank $\left.=n\right)$. Pre- and post-drainage SI $\left(\mathrm{SI}_{1984}\right.$ and $\mathrm{SI}_{2002}$, respectively) have been evaluated for the three tallest stems of each SIZE class for each subplots using Eq. 1. Mean values of $\mathrm{SI}_{1984}$ and $\mathrm{SI}_{2002}$ have been calculated for each subplot, irrespective of tree size, in order to give an overall estimate of the stand productivity following drainage. The method used to estimate the SI results in the representation of the average site productivity that the stand has shown up to the moment of measurement. Therefore, the calculated value of $\mathrm{SI}_{2002}$ sums up both the growth exerted

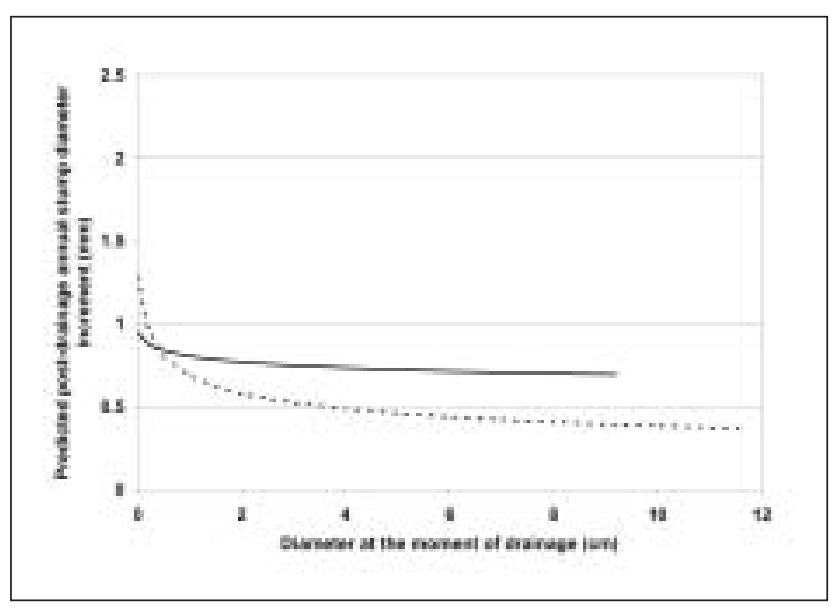

Fig. 3. Initial black spruce dimensions as a tree growth factor on a drained unproductive peatland stand. Predicted values were calculated from the model parameter estimates (Eq. 3 and 4) with a fixed distance to the center of the ditch (DIST $=11.68$ $\mathrm{m}$. The thick line refers to the trees closest to the UP-slope ditch while the dotted line refers to trees closest to the DOWNslope ditch.

before drainage $\left(\mathrm{SI}_{1984}\right)$ and that occurred after drainage $\left(\mathrm{SI}_{1984-2002}\right)$. In order to isolate the single effect of drainage on site productivity, the effective post-drainage SI $\left(\mathrm{SI}_{1984-2002}\right)$ was therefore estimated by compensating for the predrainage growth using Eq. 2, which assumes that $S I_{2002}$ is the time-weighted average of pre- and post-drainage SI.

[2]

$$
S I_{1984-2002}=\frac{\left(\left(S I_{2002} \cdot A_{2002}\right)-\left(S I_{1984} \cdot A_{1994}\right)\right)}{18}
$$

\section{Results}

The statistical analysis demonstrated the significant influence of initial stem dimension, the distance to the ditch, and the reference ditch used on black spruce growth (Table 2). The mean stem characteristics in 1984 showed small variations among plots (Table 1), which were accounted for in the model by the random plot effect. This random effect almost showed a significant effect $(p=0.0882)$. The model fit, calculated with the Nagelkerke (1991) pseudo- $\mathrm{R}^{2}$, was 0.48 . The model's parameter estimation enabled the construction of the following equations:

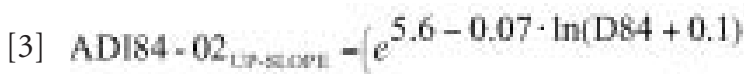
$+0.27 \cdot$ DIST $^{-2.6} \cdot$ DIST $^{-5}-3.6 \cdot$ DIST $\left.^{-1}\right)$

[4]

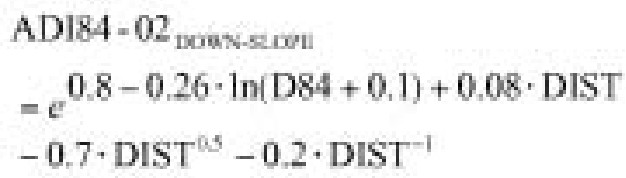

The diameter at the time of drainage $(\ln (\mathrm{D} 84))$ and the $\ln ($ D84 $) \times$ DITCH interaction significantly influenced the mean post-drainage annual stump diameter increment $(\ln ($ ADI84-02)) (Table 2). Small trees exhibited larger diameter increments than did large trees (Fig. 3). Trees with distances associated with the UP-SLOPE ditch showed fewer 


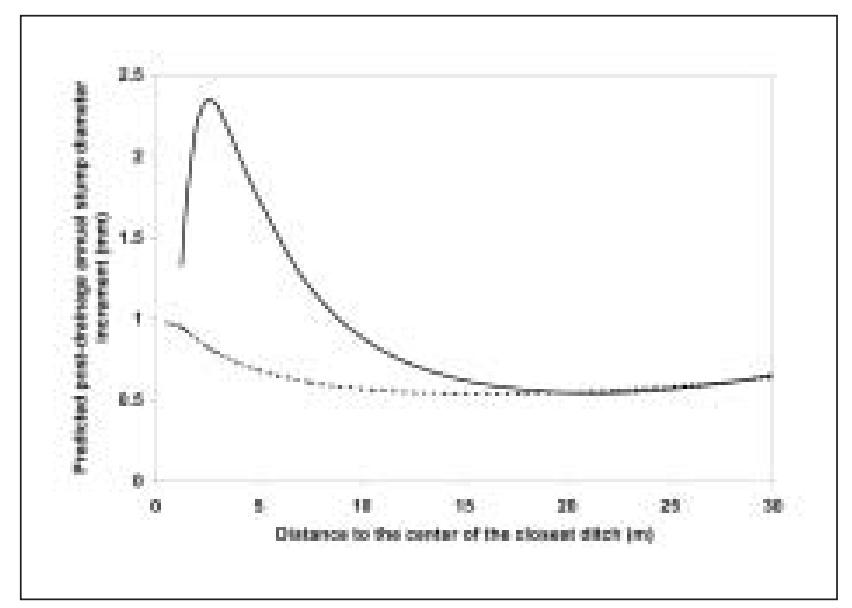

Fig. 4. Effects of ditch proximity on black spruce growth in a drained unproductive peatland stand. Predicted values were calculated from the model parameter estimates (Eq. 3 and 4) with a fixed diameter at the moment of drainage (D84 $=2.48 \mathrm{~cm}$ ) The thick line refers to the trees closest to the UP-slope ditch while the dotted line refers to trees closest to the DOWN-slope ditch.

differences in growth between small and large stems than those that were measured towards the DOWN-SLOPE ditch. Trees exceeding $0.5 \mathrm{~cm}$ of stump diameter showed greater annual stump diameter increments when located on the UPSLOPE position compared to the DOWN-SLOPE position.

DIST, DIST ${ }^{0.5}$, DIST $^{-1}$ and their respective interactions with DITCH were all found to have significant influence on the dependent variable (Table 2). The difference in growth reaction with respect to DITCH was evident within the first $15 \mathrm{~m}$ from the ditch (Fig. 4). The highest diameter increments were observed for trees located around $2.5 \mathrm{~m}$ from the UPSLOPE ditch. Trees found on the DOWN-SLOPE side reacted to drainage only within the first few meters from the ditch (Fig. 4). Trees that were located farther than $15 \mathrm{~m}$ from a ditch showed comparable diameter growth for both DITCH classes.

Estimated values of SI were plotted as a function of

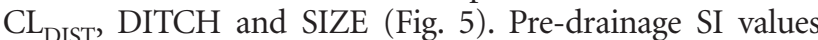
$\left(\mathrm{SI}_{1984}\right)$ averaged $2.6 \mathrm{~m}$ and rarely exceeded $3 \mathrm{~m}$. Effective post-drainage SI values $\left(\mathrm{SI}_{1984-2002}\right)$ were highest for small stems located close to the UP-SLOPE ditch (Fig. 5a). The overall estimate of the stand productivity following drainage showed significant SI increment only for stems situated within the first $10 \mathrm{~m}$ from the ditches (Fig. 5d). Accordingly, the effective post-drainage SI $\left(\mathrm{SI}_{1984-2002}\right)$ was almost equal to the post-drainage $\mathrm{SI}\left(\mathrm{SI}_{2002}\right)$ for small trees because their predrainage growth period was relatively short.

\section{Discussion}

\section{Diameter growth assessment}

It seems obvious that the reference ditch has played a very important role in the post-drainage mean annual stump diameter increment. This factor explained significant differences in tree growth reaction following drainage. It appears, however, that this factor was not taken into consideration in the original experimental design since the presence of excavated soil mounds were systematically found on the same side of the ditches. The improperly replicated mound locations made it impossible to determine the effect of the reference ditch influence on tree growth. It could have been the consequence of varying soil conditions that were triggered by differing shapes of the water table along each side of the drained strip. For example, in the absence of the mounds on one side, the commonly observed arch-shaped form of the water table height between two ditches (Berry and Jeglum 1991, Hillman 1992, Prévost et al. 1997) can be slightly tilted, showing lower water table levels on the high side of the drained strip compared to the low side (Braekke 1983). However, on our gently sloped study area $(<0.5 \%$ slope), we supposed that only small differences between water table levels on opposite sides of the drained strip would have been observed. Consequently, only minor differences in tree growth would have been explained by ditch localisation.

Another, more probable explanation for the observed tree growth difference with respect to the reference ditch was the systematic presence of excavation mounds on the lower side of the ditches within $2 \mathrm{~m}$ and $6 \mathrm{~m}$ distance from the center of the ditch. These mounds, made of dark and well-decomposed peat, could have enhanced local soil conditions by leaching nutrients into the soil. On the DOWN-SLOPE ditch side, soil conditions were likely enhanced only by lowering of the water table caused by drainage, since excavated material was never laid on this side of the ditch. Tree growth and site productivity differences observed between UP-SLOPE and DOWNSLOPE positions of the reference ditch were consequently largely attributed to the presence of excavating mounds on the UP-SLOPE ditch side.

The observed higher diameter growth of small trees compared to larger ones (Fig. 3) was consistent with earlier observations from other drainage experiments (Dang and Lieffers 1989, Macdonald and Yin 1999). Small trees, which were normally represented by young stems with vigorous green crowns, logically had superior abilities to take advantage of new soil conditions induced by drainage compared to large trees. This presumes that the inter-tree competition does not limit small trees to respond, which is commonly the case in uneven-aged, very low-stocked, unproductive stands. Larger trees often were old stems showing narrow tufted living crowns. However, the small growth difference observed between small and large stems located close to the UP-SLOPE ditch revealed that, in these sections of the drained site, the treatment might have more equitably affected the growth of all stems. In the absence of excavation mounds, i.e., DOWN-SLOPE, large stems generally showed annual stump diameter increments lower than $0.5 \mathrm{~mm} / \mathrm{y}$, a result comparable to pre-drainage growth increments (Table 1).

The arch-shaped form of the water table between two ditches is the principal cause of gradually enhanced soil growing conditions with increasing ditch proximity (Roy et al. 2000). Most studies that assess lowering of water table levels following drainage in organic soils have demonstrated that the significant effect of this treatment was limited to the first 10 to $15 \mathrm{~m}$ from the ditch (Belleau et al. 1992, Prévost et al. 1997, Jutras and Plamondon 2005). The mean annual stump diameter increments were also higher within the first $15 \mathrm{~m}$ from the ditch in this study and varied as a function of ditch proximity. However, at 15 to $30 \mathrm{~m}$ from the ditch, the diameter increments showed low and constant values 

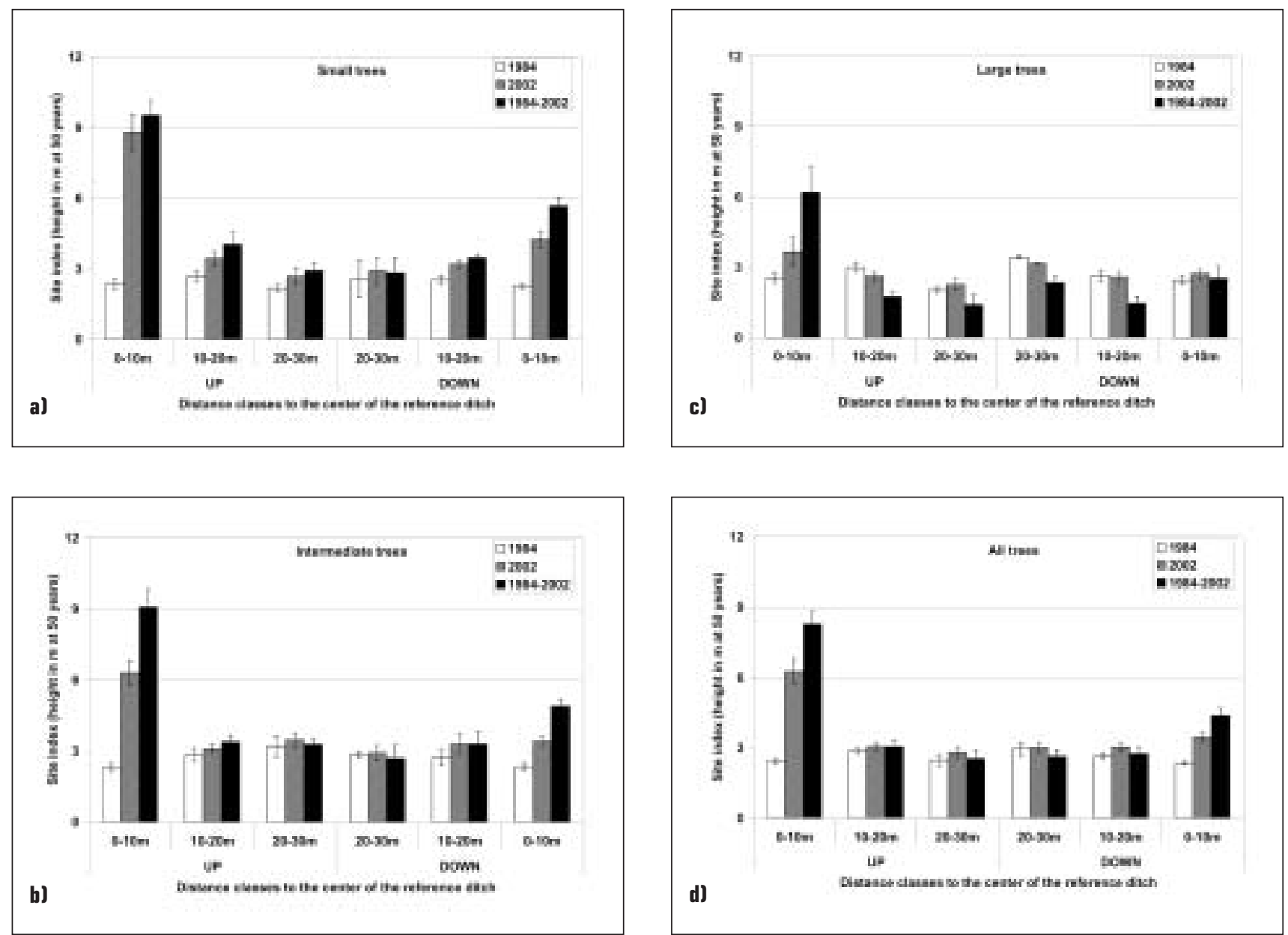

Fig. 5. Influence of ditch proximity and tree size on site productivity in a drained unproductive peatland stand. Pre-drainage $\left(\mathrm{SI}_{1984}{ }_{1}\right.$, post-drainage $\left(\left.S\right|_{2002}\right.$ ) and effective post-drainage $\left(\mathrm{SI}_{1984-2002}\right.$ ) SI estimations shown for small (a), intermediate (b) and large stems (c). The mean SI values, irrespective of the size of the stem, are also shown (d). Error bars represent \pm SE.

regardless of the distance to the ditch or the reference ditch used. These observations confirmed the absence of significant drainage effects farther than $15 \mathrm{~m}$ from the ditch.

Drainage enhanced growth within the first $15 \mathrm{~m}$ from the ditch, but important variations were observed with respect to the ditch used as reference. On the DOWN-SLOPE ditch side, the highest diameter increments were found within the first 5 $\mathrm{m}$, showing evidence of the spatially restricted amelioration of the soil growing conditions caused by water table drawdown in weakly decomposed organic soils. On the opposite side of the plot (DITCH = UP-SLOPE), higher diameter increments were observed since trees were simultaneously influenced by the effect of drainage and the presence of decomposing organic mounds. The much larger diameter growth between 1.5 and $2.5 \mathrm{~m}$ from the UP-SLOPE ditch could mainly be explained by modelling shortcomings. In presence of only the DIST and DIST ${ }^{0.5}$ factors in the model, tree growth would rise exponentially with increasing ditch proximity. The DIST ${ }^{-1}$ factor was mainly responsible for limiting the exponential shape of the curve, but diameter growth was underestimated for very low values of distance to the ditch. Biased growth estimation by the model could also have been caused by the poor representation of very low distance to the ditch values within the data set. Observations found in this specific area (DIST $<2.5 \mathrm{~m}, \mathrm{DITCH}=\mathrm{UP}-$ SLOPE) represented only $4 \%$ of the whole data set. From 2.5 $\mathrm{m}$ to $15 \mathrm{~m}$, the mean annual stump diameter increment gradually decreased, following the pattern of average water table level across the strip which has been observed in several studies (Berry and Jeglum 1991, Hillman 1992, Prévost et al. 1997).

The results obtained confirmed the first hypothesis, since black spruce diameter increment was significantly greater for small trees compared to large trees and for those located in the first few meters from the ditch compared to the ones located farther away. Moreover, the influence of excavation mounds on tree growth was pronounced, since post-drainage mean annual stump diameter increments showed significant differences with respect to the presence or absence of such mounds.

\section{Stand productivity estimation}

Using Payandeh's (1990) yield tables, the mean value of the overall estimated $\mathrm{SI}_{1984}$ of $2.6 \mathrm{~m}$ corresponds to a merchantable volume at 120 years of $10.2 \mathrm{~m}^{3} / \mathrm{ha}$, a value that didn't meet Quebec minimum productivity criteria (Saucier 
1994). This confirms the unproductive state of the treated site before drainage.

The procedure used to evaluate the change in SI induced by drainage was based on the comparison of the site productivity estimated at the time of drainage to its productivity 18 years later. It was expected that this 18 -year period included a growth reaction delay of a few years (Dang and Lieffers 1989) and a maximum growth effect of the treatment, normally occurring between 13 to 19 years after drainage (Dang and Lieffers 1989). These events were expected to generate both negligible and beneficial effects, respectively, on tree growth and site productivity. For these reasons, the results obtained for this 18 -year period were considered to reasonably represent an average growth response caused by drainage. Such growth response is likely to be maintained for up to 30 years following treatment since ditches in boreal peatlands show reduced water flow capacities after 20 to 30 years (Hökkä et al. 2000).

Post-drainage site productivity, as estimated by $\mathrm{SI}_{1984-2002}$, showed similar results to those obtained with the diameter growth assessment. The beneficial growth influence of mounds, present on the UP-SLOPE ditch side, was also detected since the highest $\mathrm{SI}_{1984-2002}$ values were observed along that reference ditch. The site productivity illustrated by the small stems showed much stronger reaction to drainage than larger ones, especially for the subplots located close to the ditch. Corresponding results about better height growth response of young Scots pine (Pinus sylvestris L.) trees to drainage have been obtained by Heikurainen and Kuusela (1962) and Hökkä and Ojansuu (2004). The overall SI estimation, merging the SI of all tree sizes, indicated that no difference was found between pre- and post-drainage site productivity for subplots located farther away than $10 \mathrm{~m}$ from the ditch, which again confirmed the spatially restricted effect of drainage.

The second hypothesis had therefore to be rejected since it was believed at first that site productivity would never be reached on a drained unproductive black spruce peatland stand. Stand productivity (SI $>3.0 \mathrm{~m}$ at age 50 years) was observed, but only within the first $10 \mathrm{~m}$ from the center of the ditch. Possibly a productive stand could be generated in this limited area, but it is unlikely that such site productivity would persist without regular ditch network maintenance throughout a stand rotation. Flow reduction is expected due to ditch deterioration caused by peat subsidence, wall collapse and erosion (Paavilainen and Päivänen 1995), and in the black spruce peatlands also due to the beaver dams.

The results gathered in this study have to be used cautiously for numerous reasons. Whoever would be interested in draining unproductive peatland sites should not expect to harvest any merchantable stems before 80 years after drainage. Besides, the estimated post-drainage productivity, based on an 18-year period of observation, might not be representative of such a long expected harvest rotation. The observed SI values were also greatly influenced by the presumed nutrient leaching of the excavated material although this phenomenon was very little documented. How long will this favourable effect prevail? Would the spreading of the excavated material in numerous smaller mounds, located on both sides of the ditch result in equivalent site productivity? These questions don't have precise answers but they could have an important impact on yield estimations. Our study did not consider either the physical presence of open ditches where trees will never grow or the need of ditch maintenance in the coming years. The results suggested that with 20-m spacing more even growth rate of trees could have been obtained. This, however, means that a considerable proportion of the area potential for growing trees should be reserved for the ditches (up to 15-20\%, depending on the width of the ditch openings). Over a long expected harvest rotation, ditches will need to be cleaned after a few decades to sustain their water flow capacities. The necessary passage of the excavation machinery required for ditch maintenance will destroy vegetation existing within a $3-\mathrm{m}$ to $4-\mathrm{m}$ wide strip, depending on the machinery used. Before supporting the use of intensive drainage in unproductive black spruce peatland sites, it would also be necessary to evaluate its economic profitability and environmental impacts. In the absence of appropriate information concerning these subjects, we would urge caution and suggest that such treatments should not be undertaken.

\section{Conclusion}

Individual tree growth and site productivity were favourably enhanced by drainage on the unproductive black spruce peatland site under study. However, the influence of drainage was limited such that only narrow ditch spacing would enable the transformation of entire sites into productive stands.

\section{Acknowledgements}

The authors would like pay tribute to Dr. Hassan Ali Bolghari (1938-1992), who established in 1983 the innovative experimental area where the study was performed. We are grateful to Art Groot and to the two anonymous reviewers for their constructive comments. This research was supported by the Quebec Ministry of Natural Resources and Wildlife and Les Chantiers de Chibougamau Ltée. through the Programme de mise en valeur des ressources du milieu forestier - Volet. The first author was financially supported by a doctoral scholarship from FQRNT (Fonds québécois de la recherche sur la nature et les technologies).

\section{References}

Belleau, P., A.P. Plamondon, R. Lagacé and S. Pepin. 1992. Hydrodynamique d'une pessière noire drainée. Can. J. For. Res. 22: 1063-1070.

Bergeron, J.F., P. Grondin and J. Blouin. 1998. Rapport de classification écologique du sous-domaine bioclimatique de la pessière à mousses de l'ouest. Ministère des Ressources naturelles du Québec, Direction des inventaires forestiers. $178 \mathrm{p}$.

Berry, G.J. and J.K. Jeglum. 1991. Hydrology of drained and undrained black spruce peatlands: groundwater table profiles and fluctuations. For. Can., Ont. Region, Sault Ste. Marie, Ont. COFRDA Rep. $3307.31 \mathrm{p}$.

Bolghari, H. 1986. Perspectives du drainage forestier au Québec. In Ordre des Ingénieurs Forestiers du Québec (ed.). Colloque sur le drainage forestier, 10-11 sept. 1985, Ste-Foy, Québec. pp. 47-65.

Bolghari, H. and J.-M. Veilleux. 1987. Évaluation du drainage forestier comme technique de préparation du terrain pour régénérer par différentes méthodes (plantations, ensemencements naturels et artificiels) les pessières noires humides récemment exploitées. Projet R82315. Ministère de l'Énergie et des Ressources, Québec. 8 p.

Braekke, F.H. 1983. Water table levels at different drainage intensities on deep peat in northern Norway. For. Ecol. Manage. 5: 169-192. 
Coulombe, G., J. Huot, J. Arsenault, E. Bauce, J.-T. Bernard, A. Bouchard, M.A. Liboiron and G. Szaraz. 2004. Commission d'étude sur la gestion de la forêt publique québécoise. Québec. 307 p.

Dang, Q.L. and V.J. Lieffers. 1989. Assessment of patterns of response of tree ring growth of black spruce following peatland drainage. Can. J. For. Res. 19: 924-929.

Environment Canada. 2004. Canadian climate normals 1971-2000. Atmospheric Environment Service, Downsview, ON.

Heikurainen, L. 1964. Improvement of forest growth on poorly drained peat soils. Int. Rev. For. Res. 1. pp. 39-113. Academic Press, New York.

Heikurainen, L. 1968. Peatlands of Newfoundland and possibilities of utilizing them in forestry. Can. For. Serv., For. Res. Lab. Inf. Rep. $\mathrm{N}-\mathrm{X}-16.57 \mathrm{p}$.

Heikurainen, L. and K. Kuusela. 1962. Revival of the tree growth after drainage and its dependence on tree size and age. Commun. Inst. For. Fenn. 55(8).15 p.

Hillman, G.R. 1987. Improving wetlands for forestry in Canada. Can. For. Serv. Inf. Rep. NOR-X-288. 29 p.

Hillman, G.R. 1991a. Black spruce growth on drained, forested peatland in northern Alberta. Can. For. Serv. For. Manag. Note No. $53.8 \mathrm{p}$.

Hillman, G.R. 1991b. The Canada-Alberta wetlands drainage and improvement program for forestry: an update. In J.K. Jeglum R.P. and R.P. Overend (eds.). Proceedings, Peat and Peatlands: Diversification and Innovation, 6-10 Aug. 1989, Québec City, Que. pp. 54-61.Canadian Society for Peat and Peatlands, Darmouth, NS. Hillman, G.R. 1992. Some hydrological effects of peatland drainage in Alberta's boreal forest. Can. J. For. Res. 22: 1588-1596.

Hillman, G.R. and S.K. Takyi. 1998. Response of black spruce to thinning and fertilization in a drained swamp. North. J. Appl. For. 15: 98-105.

Hökkä, H., V. Alenius and H. Salminen. 2000. Predicting the need for ditch network maintenance in drained peatland sites in Finland. Suo 51(1): 1-10.

Hökkä, H. and R. Ojansuu. 2004. Height development of Scots pine on peatlands: describing change in site productivity with a site index model. Can. J. For. Res. 34: 1081-1092.

Jeglum, J.K. 1991a. The Wally Creek Area Forest Drainage Project in Ontario Clay Belt: Progress Report. In J.K. Jeglum R.P. and R.P. Overend (eds.). Proceedings, Peat and Peatlands: Diversification and Innovation, 6-10 Aug. 1989, Québec City, Que.pp. 47-53. Canadian Society for Peat and Peatlands, Darmouth, NS.

Jeglum, J.K. 1991b. Concluding comments and recommendations. In J.K. Jeglum R.P. and R.P. Overend (eds.). Proceedings, Peat and Peatlands: Diversification and Innovation, 6-10 Aug. 1989, Québec City, Que. pp. 223-227. Canadian Society for Peat and Peatlands, Darmouth, N.S.

Jeglum, J.K. 1991c. Definition of trophic classes in wooded peatlands by means of vegetation types and plant indicators. Ann. Bot. Fenn. 28: 175-192.

Jones, R.K., G. Pierpoint, G.M. Wickware, J.K. Jeglum, R.W. Arnup and J.M. Bowles. 1983. Field guide to forest ecosystem classification for the Clay Belt, site Region 3e. Ontario Ministry of Natural Resources, Maple, Ontario. 123 p.

Jutras, S. and A.P. Plamondon. 2005. Water table rise after harvesting in a treed fen previously drained for forestry. Suo 56: 95-100.

Jutras, S. J. Bégin and A.P. Plamondon. 2002. Impact du drainage forestier après coupe sur la croissance de l'épinette noire en forêt boréale. Can. J. For. Res. 32: 1585-1596.

Lieffers, V.J. 1988. Sphagnum and cellulose decomposition in drained and natural areas of an Alberta peatland. Can. J. Soil Sci. $755-761$.

Lieffers, V.J. and S.E. Macdonald. 1990. Growth and foliar nutrient status of black spruce and tamarack in relation to depth of water table in some Alberta peatlands. Can. J. For. Res. 20: 805-809.

Lieffers, V.J. and R.L. Rothwell. 1986. Effects of depth of water table and substrate temperature on root and top growth of Picea mariana and Larix laricina seedlings. Can. J. For. Res. 16: 1201-1206.

Lieffers, V.J. and R.L. Rothwell. 1987. Effects of drainage on substrate temperature and phenology of some trees and shrubs in an Alberta peatland. Can. J. For. Res. 17: 97-104.

Macdonald, S.E. and F. Yin. 1999. Factors influencing size inequality in peatland black spruce and tamarack: evidence from post-drainage release growth. J. Ecol. 87: 404-412.

McLaren, B.E. and J.K. Jeglum. 1998. Black spruce growth and foliar nutrient responses to drainage and fertilisation: Wally Creek, Ontario. For. Chron. 74: 106-115.

Nadeau, J.-P. and B. Parent. 1982. L'économique du drainage forestier au Québec. Ministère de l'Énergie et des Ressources, Service de la Recherche, Québec. Mémoire no. 80.177 p.

Nagelkerke, N. J. D. 1991. A note on a general definition of the coefficient of determination. Biometrika 78: 691-692.

Paavilainen, E. and J. Päivänen. 1995. Peatland forestry: ecology and principles. Springer-Verlag, Berlin. 248 p.

Päivänen, J. and E.D. Wells. 1978. Guidelines for the development of peatland drainage systems for forestry in Newfoundland. Can. For. Serv. Inf. Rep. N-X-156. 44 p.

Payandeh, B. 1973a. Analyses of a forest drainage experiment in northern Ontario. I: Growth analysis. Can. J. For. Res. 3: 387-398.

Payandeh, B. 1973b. Analyses of a forest drainage experiment in northern Ontario. II: An economic analysis. Can. J. For. Res. 3: 399-408.

Payandeh, B. 1975. Growth and economic analyses of a forest drainage experiment in northern Ontario. In Can. For. Serv. (ed.) Proc. of the Black Spruce Symp., Thunder Bay, Ontario, Canada, Sept. 23-25, 1975. pp. 61-76.Symp. Proc. O-P-4.

Payandeh, B. 1978. A site index formula for peatland black spruce in Ontario. For. Chron. 54: 39-41.

Payandeh, B. 1982. Five-year growth response of northern Ontario peatland black spruce to fertilization and drainage. Can. For. Serv. Inf. Rep. 0-X-340. 20 p.

Payandeh, B. 1989. Growth of black spruce trees following fertilization on drained peatland. For. Chron. 65: 102-106.

Payandeh, B. 1990. Preliminary yield functions and tables for peatland black spruce in Ontario. Can. For. Serv. Inf. Rep. 0-X-405. $10 \mathrm{p}$.

Plonski, W.L. 1974. Normal yield tables (metric) for major forest species of Ontario. Ontario Ministry of Natural Resources, Toronto, ON.

Pollett, F.C. 1969. A program for the development of peatland forestry in Newfoundland. Can. For. Serv., For. Res. Lab., Inf. Rep. N$\mathrm{X}-29.28 \mathrm{p}$.

Prévost, M., P. Belleau and A.P. Plamondon. 1997. Substrate conditions in a treed peatland: Responses to drainage. Ecoscience 4: 543-554.

Prévost, M., D. Dumais and A.P. Plamondon. 2005. Effets du drainage sur la croissance et le statut nutritif d'un peuplement d'épinette noire de structure inéquienne: résultats de 10 ans. For. Chron. 81: 516-524.

Prévost, M., A.P. Plamondon and P. Belleau. 1999. Effects of drainage of a forested peatland on water quality and quantity. J. Hydrol. 214: 130-143.

Rosen, M. 1989. Forest drainage manual. Ont. Min. Nat. Resour., Cochrane, Ont. Sci. and Tech. Ser. Vol 4. 32 p.

Roy, V., A.P. Plamondon and P. Bernier. 2000. Draining forested wetland cutovers to improve seedling root zone conditions. Scand. J. For. Res. 15: 58-67.

SAS Institute Inc. 2003. SAS OnlineDoc ${ }^{\circledR}$, Version 9.1. SAS Institute Inc., Cary, NC.

Saucier, J.-P. 1994. Le point d'observation écologique : normes techniques. Direction de la gestion des stocks forestiers, Service des inventaires forestiers, Ministère des Ressources naturelles, Québec. $116 \mathrm{p}$. 
Stanek, W. 1968. A forest drainage experiment in northern Ontario. Pulp Pap. Mag. Can. 69: 58-62.

Stanek, W. 1970. Amelioration of water-logged terrain in Quebec. I: Description of the area, hydrology and drainage. Can. For. Serv. Inf. Rep. Q-X-17. 18 p.

Stanek, W. 1977. Ontario clay belt peatlands - are they suitable for forest drainage? Can. J. For. Res. 7: 656-665.

Sundström, E. 1992. Five-year growth response in drained and fertilised black spruce peatlands. I. Permanent growth plot analysis. NEST Tech. Rep. TR-02 / For. Can. Inf. Rep. 0-X-417. 19 p.

Sundström, E. and J.K. Jeglum. 1992. Five-year growth response in drained and fertilised black spruce peatlands. II. Stem analysis. NEST Tech. Rep. TR-03 / For. Can. Inf. Rep. 0 X-420. 13 p.
Wang, E.I.C., T. Mueller and M.M Micko. 1985. Drainage effect on growth and wood quality of some bog grown trees in Alberta. For. Chron. 61: 489-493.

Zarnovican, R. 1989. Suivi des travaux de drainage forestier : 1) Production forestière et caractéristiques écologiques des massifs de Saint-Anaclet et de Cabano. Forêts Canada, Région de Québec. Inf. Rep. LAU-X-90. 37 p.

Zarnovican, R. and C. Laberge. 1994. Suivi des travaux de drainage forestier : 2) Effet du drainage sur la croissance de l'épinette noire et du mélèze laricin à Saint-Anaclet. Forêts Canada, Région de Québec. Inf. Rep. LAU-X-107. 26 p. 